\title{
Carbon Stock and Soil Characteristics under Expansive Shrubs in the Dry Afromontane Forest in Northern Ethiopia
}

\author{
Mebrahtu Haile $\mathbb{D D}^{1}{ }^{1}$ Emiru Birhane $\mathbb{D}^{1},{ }^{1}$ Meley Mekonen Rannestad, ${ }^{2}$ \\ and Muyiwa S. Adaramola $\mathbb{( D}^{2}$ \\ ${ }^{1}$ Department of Land Resources Management and Environmental Protection, Mekelle University, P.O. Box 231, Mekelle, Ethiopia \\ ${ }^{2}$ Faculty of Environmental Sciences and Natural Resource Management, Norwegian University of Life Sciences (NMBU), \\ Ass, Norway
}

Correspondence should be addressed to Mebrahtu Haile; mebrahtu.haile@yahoo.com

Received 8 October 2020; Accepted 27 April 2021; Published 30 May 2021

Academic Editor: Nikolaos D. Hasanagas

Copyright ( ) 2021 Mebrahtu Haile et al. This is an open access article distributed under the Creative Commons Attribution License, which permits unrestricted use, distribution, and reproduction in any medium, provided the original work is properly cited.

\begin{abstract}
Increased presence of expansive plant species could bring about various ecological influences on biomass carbon, soil organic carbon, and the physical and chemical properties of the soils. However, their impacts on these ecological parameters could differ due to a wide range of life forms, plant communities of the invaded ecosystems, and abiotic conditions. This work was conducted to examine the impacts of Cadia purpurea and Tarchonanthus camphoratus cover on carbon stock in vegetation and soil and soil physicochemical properties in Desa'a forest, northern Ethiopia. Vegetation and soil data were collected from a total of 150 sampling plots (size $20 \mathrm{~m} \times 20 \mathrm{~m}$ ) from uninvaded and invaded vegetation conditions. The soil samples were collected from topsoil $(0-15$ and $15-30 \mathrm{~cm})$ of the uninvaded and invaded vegetation conditions. The statistical difference in carbon stock and soil characteristics $(P<0.05)$ of both invaded and uninvaded vegetation conditions were tested using an independent $t$-test using an $\mathrm{R}$-software. The mean above- and below-ground biomass carbon stocks of the uninvaded vegetation condition $(17.62 \mathrm{Mg} \cdot \mathrm{C} / \mathrm{ha}$ and $4.14 \mathrm{Mg} \cdot \mathrm{C} / \mathrm{ha}$, respectively) were found to be significantly higher than those of the invaded vegetation condition $(4.73 \mathrm{Mg} \cdot \mathrm{C} /$ ha and $1.11 \mathrm{Mg} \cdot \mathrm{C} / \mathrm{ha}$, respectively). The mean soil organic carbons (SOC) were significantly higher $(P<0.01)$ in the uninvaded $(122.83 \mathrm{Mg} \cdot \mathrm{C} / \mathrm{ha})$ than in the invaded $(90.13 \mathrm{Mg} \cdot \mathrm{C} / \mathrm{ha})$ vegetation condition. The total carbon stock estimates were significantly higher $(P<0.01)$ in the uninvaded vegetation condition $(144.59 \mathrm{Mg} \cdot \mathrm{C} / \mathrm{ha})$ than in the invaded vegetation condition $(95.97 \mathrm{Mg} \cdot \mathrm{C} /$ ha). Furthermore, the result revealed that most of the soil characteristics were significantly lower $(P<0.05)$ under the expansive shrubs invaded vegetation conditions except for significantly high sand content $(P<0.05)$. Silt, nitrogen, phosphorus, calcium, copper, and zinc did not significantly change with the cover of the expansive shrubs. Our results suggest that increased presence of the expansive species decreased carbon trapping and affected most of the soil nutrients within the forest. Hence, to enhance the carbon storage potential and to maintain the soil nutrient status of the forest, proper conservation, monitoring, and management of the existing PNV and controlling a further expansion of the expansive shrubs are required. Further studies will be required on the factors responsible for the difference in carbon stocks and soil nutrients in each vegetation condition in addition to the impacts of the expansive shrubs expansion.
\end{abstract}

\section{Introduction}

Invasive and expansive plant species have been globally recognized as severe ecological threats in recent decades, which affect the forest ecosystem services [1-6]. The invasive and expansive plant species have similar detrimental consequences and common characteristics $[7,8]$. They both can produce high-quality seeds and regenerate and establish easily and grow fast in a wide range of geographical areas and environmental conditions [9]. Invasive and expansive species differ in that the expansive species are native plants spreading in the landscape after changes in land management, whereas the invasive species are introduced plants with self-reproduction in areas distant from the sites of 
introduction [10]. The highly competitive ability of the invasive species colonizes new localities, often at the expense of native species [11]. Expansive species are species that expand their distribution and colonize new habitats in an area where they are native [8]. They can displace or considerably suppress native plants through superior competitiveness, altering ecosystem processes, or disturbance regimes [12]. Expansion by expansive plant species could bring about various ecological influences on biomass carbon, soil organic carbon, and physical and chemical properties of the soils as they have fast growth and high nutrient uptake potentials $[1,3,5,13-17]$.

Some studies found that expansive species expansion increases carbon stock $[5,18,19]$ and soil nutrients $[17,20]$. In contrast, the expansion of expansive species resulted in a carbon stock decrease in some areas $[15,21]$. Hence, understanding the vegetation and soil carbon changes with the expansion of expansive species is very essential, considering the recent attention in the carbon balance of the tropics $[5,20]$. The expansive species could have higher or lower $\mathrm{CO}_{2}$ sequestration potential and ability to moderate climate change than the Potential Natural Vegetation (PNV). PNV refers to the mature vegetation that would establish given a particular set of environmental constraints but excluding the effects of humans [22].

Furthermore, expansion of expansive species can result in various impacts on nutrient exchanges, as expansive species commonly have stronger growth potentials [1]. However, they could have positive or negative impacts on soil fertility [3,23]. Seitz et al. [24] indicated that changes in the composition of plant communities directly influence soil characteristics, with soil processes responding to the composition of the plant community. Some studies indicated that expansion by expansive plants increases nutrient pools and enhances the rate of soil processes such as litter decomposition and mineralization [1]. They alter soil-nutrient regimes by initially changing community composition [3]. The fast-growing expansive species alter the nutrient cycle directly through their competitive nutrient uptake and poor nutrient use efficiency and by modifying the quality and quantity of the litter entering the soil or indirectly through the activity of roots and the alteration of microclimates below their canopy $[17,25]$.

The two expansive shrubs in this study, Cadia purpurea (C. purpurea) and Tarchonanthus camphoratus (T. camphoratus), are perennial native shrubs expanded extensively in Desa'a dry Afromontane forest (hereafter Desa'a forest) in northern Ethiopia. The study by Haile et al. [23] indicated a shift in woody plant species composition, and the impacts on plant diversity and regeneration status followed the expansion of expansive shrubs in the forest. Population structure indicators like diameter, height, and mean basal area of the plant species were also declined with the expansion of the expansive shrubs [23]. Besides, despite the species and site-specific nature of the expansive plant species, both negative and positive impacts of expansion on different ecological aspects have been reported $[3,5,13,15,19]$. The spatial distribution [26], the expansion factors, and the impacts of both expansive shrubs
(C. purpurea and T. camphoratus) on plant diversity, regeneration, and structure [23] were previously evaluated. However, the impacts of the two expansive species on carbon stock and soil characteristics have not been reported yet, while it is important that they are documented. Hence, considering the spatial distribution and abundance of expansive plant species, there is an urgent need to widen our comprehension on assessing the impacts of the expansion of the expansive species on ecosystem carbon sequestration and soil properties.

The goal of this work was to examine the impacts of C. purpurea and T. camphoratus cover on carbon stock and soil properties. The objectives of this study were (i) to analyze the impact of expansive shrubs (C. purpurea and T. camphoratus) cover on the above- and below-ground biomass carbon stock of the forest, (ii) to evaluate the carbon stocks of the dominant species in both vegetation conditions, (iii) to quantify the impact of expansive shrubs cover on soil organic carbon in the forest, and (iv) to evaluate the impact of expansive shrubs cover on soil physicochemical characteristics of the forest.

\section{Materials and Methods}

2.1. Study Site. The study was conducted in Desa'a dry Afromontane remnant forest in northern Ethiopia. Desa'a forest is located between $13^{\circ} 20^{\prime}$ and $14^{\circ} 10^{\prime} \mathrm{N}$ latitude and $39^{\circ} 32^{\prime}$ and $39^{\circ} 55^{\prime}$ E longitude (Figure 1). The forest is among the 58 registered National Forest Priority Areas to conserve the remnant natural forests and their genetic resources in Ethiopia. It covers two administrative regions in Ethiopia, the lowlands of Afar and the highlands of Tigray regional states, with the majority of the forest residing in Tigray regional state (Figure 1). It touches Atsbi-Womberta and Enderta districts from Tigray and Kuneba and Abala from Afar regional states. The total area of the forest is about 120,026 ha [27].

Desa'a forest stretched from the ridges of the Great East African Rift Valley towards the Dallol Basin. The forest serves as a buffer zone of the cool highlands of Tigray and the hot lowlands of Afar region [28]. More than 30\% of the slope class were found in about $45 \%$ of the area [29]. The elevation of the study area ranges between 1400 and 2800 m.a.s.l. The geological formation of the area is based on Enticho sandstone and crystalline Precambrian basement. According to Aynekulu [29], the dominant soil types of the study site include Leptosols, Vertisols, Cambisols, Arenosols, and Regosols.

Climate data were collected from Atsbi climate station $\left(13^{\circ} 52^{\prime} \mathrm{N}, 39^{\circ} 44^{\prime} \mathrm{E}\right)$ of the National Meteorological Agency of Ethiopia located near to the study site from the years of 2006-2018. Accordingly, the mean $( \pm S D)$ annual rainfall of Desa'a forest was $627( \pm 64.3) \mathrm{mm}$ (Figure 2). The average minimum and maximum monthly temperatures of the area were $9.3( \pm 0.7)^{\circ} \mathrm{C}$ and $20.1( \pm 0.5)^{\circ} \mathrm{C}$, respectively (Figure 2 ). Desa'a forest is broadly categorized as a dry Afromontane forest, which is characterized by J. procera and O. europaea as a dominant PNV. The forest is serving as a green barrier 


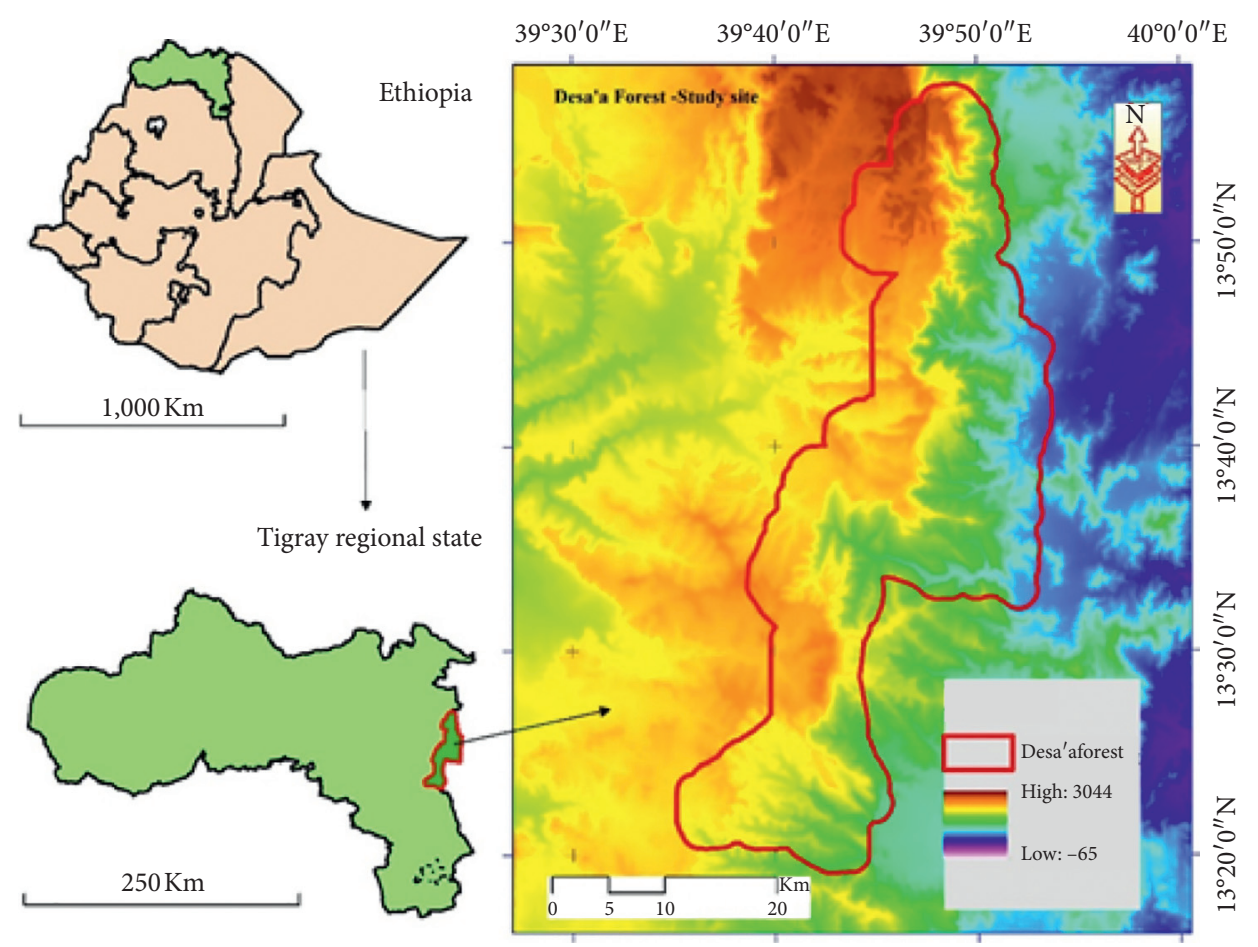

FIgURE 1: The geographical location of Desa'a forest in Ethiopia.

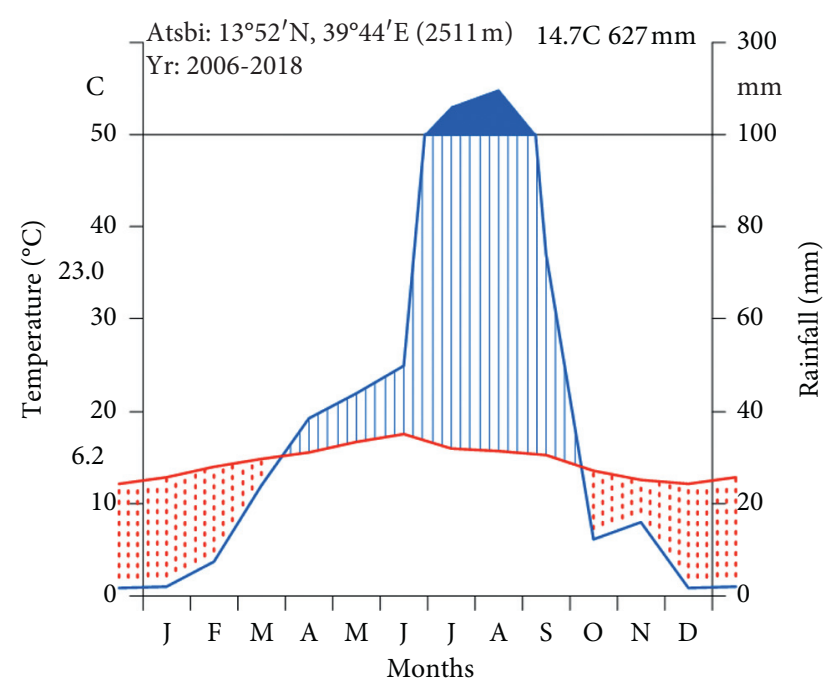

Figure 2: Mean monthly rainfall $(\mathrm{mm})$ and temperature $\left({ }^{\circ} \mathrm{C}\right)$.

against the expansion of the Danakil desert in the Afar region and the highlands of Tigray region [30].

2.2. Study Design and Sampling Techniques. A reconnaissance survey was conducted to collect preliminary information on the existing status of the forest and sampling vegetation conditions. The study area was then categorized into two vegetation conditions as "uninvaded" $(0-25 \%$ either T. camphoratus, C. purpurea, or both and dominated by J. procera and O. europaea), and "invaded" ( $\geq 50 \%$ cover of either T. camphoratus, C. purpurea, or both) by visually estimating their coverage. The visual estimation of the cover was conducted through a transect walk [31]. The two vegetation conditions were near to each other to limit unexplained fluctuation because of various environmental factors such as soil properties, rainfall regimes, and altitude. We have employed a systematic sampling technique as indicated in the work of Ellenberg and Mueller-Dombois [32]. Transect lines were laid at each vegetation condition at a distance of $100 \mathrm{~m}$ apart and plots at every $50 \mathrm{~m}$ interval along these transect lines. The starting points for the transect lines were determined and laid in a way that can maximize the number of plots using a systematic random sampling technique. The length of the transects was not uniform and they were varied according to the stratification of the vegetation conditions. The number of the plots was then determined based on the length of the transects in both vegetation conditions. The distance between the vegetation conditions was set at a minimum of $300 \mathrm{~m}$ in case of adjacent canopies to avoid the ecotones or a maximum of $2 \mathrm{~km}$ in one occasion where closer distances were practically unfeasible [33]. A total of 150 sample plots (size $20 \mathrm{~m} \times 20 \mathrm{~m}$ ) were placed along the transect lines at both vegetation conditions.

2.3. Data Collection. The vegetation and soil data collection were carried out between August and December 2018. All tree/shrub species in the plots were then identified and measured per species. In both vegetation conditions, height, diameter at breast height $(\mathrm{DBH})$ (defined at $1.3 \mathrm{~m}$ from the ground), and diameter at stump height (DSH) (at $30 \mathrm{~cm}$ from the ground) were measured using diameter tape and caliper, respectively, and recorded for each tree and shrub species. For the multistem trees and shrubs, measured at $\mathrm{DBH}$ and $\mathrm{DSH}$, we have used the following equations: 


$$
\begin{gathered}
\text { DBHe }=\sqrt{\mathrm{DBH} 1+\mathrm{DBH} 2+\mathrm{DBH} 3+\cdots}, \\
\mathrm{DSHe}=\sqrt{\mathrm{DSH} 1+\mathrm{DSH} 2+\mathrm{DSH} 3+\cdots},
\end{gathered}
$$

where DBHe is the diameter at breast height equivalent and DSHe is the diameter at a stump height equivalent.

The heights of all individual trees greater than $5 \mathrm{~m}$ height were measured in the sampling plots using clinometers at different distances based on the height of the tree from the base and were calculated using the following equation:

$$
\text { height }(m)=\frac{\text { tree top reading } \pm \text { ground reading }}{100}
$$

* the distance to the tree.

Soil samples were taken from the one at the center and the other four at the four corners of the $20 \mathrm{~m} \times 20 \mathrm{~m}$ sample plot, at depths of $0-15 \mathrm{~cm}$ and $15-30 \mathrm{~cm}$ using a sharp knife. These soil depths were selected because most of the plant root activities and root mass are concentrated there [31]. Approximately $500 \mathrm{~g}$ composite single soil samples from the same depth were mixed in the field for each given plot, resulting in a one sample per soil depth per plot. Besides, from the same plot, soil samples for soil bulk density determination were collected from the surface soil using a core sampler $\left(5 \mathrm{~cm}\right.$ diameter $\times 5 \mathrm{~cm}$ tall, $\left.98.2 \mathrm{~cm}^{3}\right)$. Then the samples were dried at ambient temperature and then passed through a $2 \mathrm{~mm}$ sieve and transferred to a soil laboratory at the Department of Geology at Mekelle University, Ethiopia, for analysis.

\subsection{Data Analysis}

2.4.1. Above-Ground Biomass Carbon (AGBC) Estimation. The above-ground biomass of trees measured at diameter at breast height $(\mathrm{DBH}, \mathrm{cm})$ was estimated using the allometric model developed by Tetemke et al. [34] using the following equation:

$$
\mathrm{AGB}=0.298 \times \mathrm{DBH}^{2.034},
$$

where AGB is above-ground biomass and $\mathrm{DBH}$ is the diameter at breast height.

Besides, above-ground biomasses (AGB) of the multistemmed trees and shrubs measured in diameter at stump height (DSH, cm) were estimated by the model developed by Tetemke et al. [34] according to the following equation:

$$
\mathrm{AGB}=0.170 \times \mathrm{DSH}^{2.128} \text {. }
$$

Above-ground biomasses of the trees and shrubs were converted to carbon following the guidelines established in the IPCC [35], which assume carbon content to be $50 \%$ of the above-ground biomasses of trees and shrubs using the following equation:

$$
\mathrm{AGBC}=\mathrm{AGB} * \mathrm{CF},
$$

where $A G B C$ is above-ground biomass carbon ( $\mathrm{Mg} / \mathrm{ha})$; $\mathrm{AGB}$ is above-ground biomass; $\mathrm{C}$ is carbon fraction (the default value is 0.50 ).
2.4.2. Below-Ground Biomass Carbon (BGBC) Estimation. Below-ground biomass (BGB), commonly known as root biomass, was determined by root-to-shoot ratio value. In this study, the below-ground biomass carbon (BGBC in $\mathrm{Mg} \cdot \mathrm{C} / \mathrm{ha}$ ) of the plant species was calculated by multiplying the above-ground biomass carbon (AGBC in $\mathrm{Mg} \cdot \mathrm{C} / \mathrm{ha}$ ) with the mean root-to-shoot ratio of 0.26 recommended for species in dry areas [36] according to the following equation:

$$
\mathrm{BGBC}=\operatorname{AGBC} x 0.26 .
$$

2.4.3. Soil Organic Carbon (SOC). The soil samples were analyzed in the soil laboratory of land resource management and environmental protection and geology department, Mekelle University, Ethiopia. Firstly, soil samples were airdried at room temperature and sieved with a $2 \mathrm{~mm}$ sieve to remove large particles like litter and debris. The samples were then oven-dried until a constant weight was maintained with the temperature of $105^{\circ} \mathrm{C}$. The SOC was then estimated following Pearson et al. [37] according to the following equation:

$$
\mathrm{SOC}=p x d x \% C,
$$

where $d$ is the total depth of the soil samples taken $(\mathrm{cm}), \% C$ is carbon concentration (\%), and $p$ is soil bulk density ( $\mathrm{g} /$ $\mathrm{cm}^{3}$ ) calculated using the following formula:

$$
p=\frac{\mathrm{ODW}}{\mathrm{CV}-(\mathrm{CF} / \mathrm{PD})},
$$

where ODW is the oven-dry weight of the soil samples in grams; $\mathrm{CV}$ is core volume $\left(\mathrm{cm}^{3}\right)$; CF is mass of the coarse fragment $(>2 \mathrm{~mm})$ in grams; PD is the density of rock fragment in $\mathrm{g} / \mathrm{cm}^{3}$, often given as $2.65 \mathrm{~g} / \mathrm{cm}^{3}$.

2.4.4. Total Carbon Stock. The total carbon stock (in Mg.C/ha) of each vegetation condition was determined by summing the three carbon pools (above-ground biomass carbon, below-ground biomass carbon, and soil organic carbon) calculated using the following equation:

$$
\mathrm{TCS}=\mathrm{AGBC}+\mathrm{BGBC}+\mathrm{SOC},
$$

where TCS is total carbon stock, AGBC is above-ground biomass carbon stock ( $\mathrm{Mg} / \mathrm{ha}), \mathrm{BGBC}$ is below-ground biomass carbon stock ( $\mathrm{Mg} \mathrm{C} / \mathrm{ha})$, and $\mathrm{SOC}$ is soil organic carbon $(\mathrm{Mg} / \mathrm{ha})$.

The $\mathrm{CO}_{2}$ equivalent was then determined by multiplying the total carbon stock by ratio of the molecular weight of carbon dioxide to that of carbon (44/12) or 3.67 [37].

2.4.5. Soil Physicochemical Analysis. The soil samples were air-dried at room temperature and sieved with a $2 \mathrm{~mm}$ sieve to remove large particles like litter and debris and homogenized, and 15 soil variables were analyzed. Soil texture was determined using the hydrometer method, soil $\mathrm{pH}$ using a $\mathrm{pH}$ meter in a $1: 2.5$ soil: water ratio, total nitrogen $(\mathrm{N})$ with Kjeldahl method, available phosphorous by Bray II 


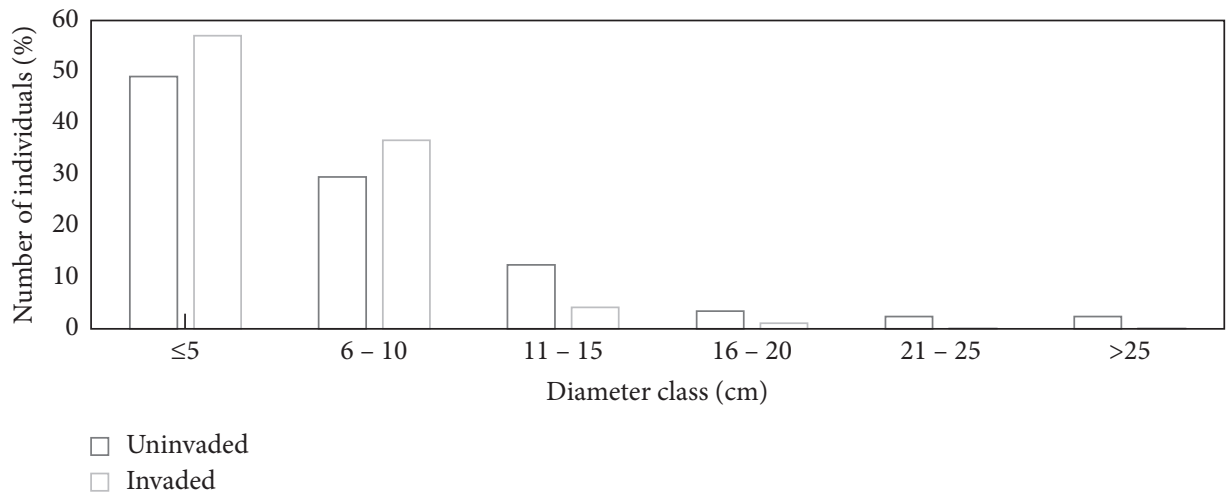

Figure 3: Diameter class distribution of woody species at both vegetation conditions.

extraction method [38], and soil organic carbon by the Walkley-Black method [39], respectively. Sodium, potassium, calcium, magnesium, and micronutrients (copper, zinc, manganese, and iron) were extracted with ethylenediaminetetraacetic acid (EDTA) and their concentration was determined with Atomic Absorption Spectrophotometer [33]. Besides, undisturbed soil samples were collected from the surface of the same plots of invaded and uninvaded vegetation conditions using core-sampler to determine bulk density. Great care has been given to avoid loss of soil while taking cores for bulk density measurement. The dry mass weights of the soil samples were determined after they were oven-dried until a constant weight was maintained at $105^{\circ} \mathrm{C}$.

2.5. Statistical Analysis. All data on carbon stocks and soil physicochemical characteristics of both uninvaded and invaded vegetation conditions were analyzed using $\mathrm{R}$ software packages [40]. Shapiro-Wilk's and Levene's statistical tests were performed to check the normal distribution and homogeneity of variances, respectively. An independent $t$-test was used to test for mean differences of carbon stocks (biomass carbon and SOC stocks) and soil physicochemical characteristics between the invaded and uninvaded vegetation conditions. Statistical mean differences were considered significant at $P<0.05$.

\section{Result}

3.1. Vegetation Characteristics. The dominant species in the uninvaded vegetation condition were found to be J. procera, O. europaea, Dodonaea angustifolia, Vachellia etbaica (Schweinf.), and Carissa edulis Vahl which contributed about $36 \%, 14 \%, 7 \%, 5 \%$, and $4 \%$, respectively. The remaining $34 \%$ was contributed by the other 57 woody species. The dominant species in the invaded vegetation condition were C. purpurea, T. camphoratus, Vachellia etbaica (Schweinf.), Rhus natalensis Bernh. ex Krauss, and other species contributing about $51 \%, 31 \%, 2 \%, 2 \%$, and $14 \%$, respectively. The total stem density of all woody species for both invaded and uninvaded vegetation conditions was found to be 1369 and $1382 \mathrm{ha}^{-1}$, respectively. It was found to be significantly different between the vegetation conditions $(P<0.015)$. Besides, average woody plant species, diameter, and height decreased significantly with the abundance of the expansive shrubs (both; $P<0.001$ ). The percentages of the woody species with DBH class $\leq 5 \mathrm{~cm}, 6-10 \mathrm{~cm}, 11-20 \mathrm{~cm}$, and $>20 \mathrm{~cm}$ were found to be $49.51 \%, 29.80 \%, 15.97 \%$, and $4.78 \%$ for uninvaded vegetation condition and $57.50 \%$ $36.95 \%, 5.3 \%$, and $0.24 \%$ for invaded vegetation condition, respectively (Figure 3 ).

\subsection{Carbon Stocks of the Dominant Species in Both Vegetation} Conditions. The top three species with a relative dominance of $99.37 \%$ in the uninvaded vegetation, namely, O. europaea (9.22 (Mg.C/ha), 42.4\%), J. procera (7.72 (Mg.C/ha), 35.5\%), and Dodonaea angustifolia $(0.48(\mathrm{Mg} \cdot \mathrm{C} / \mathrm{ha}), 2.2 \%)$, contributed about $80 \%$ carbon stock of the total biomass (Table 1). On the other hand, the top three species in the invaded vegetation condition with a relative dominance of 99.29\%, namely, C. purpurea (1.71 (Mg.C/ha), 29.3\%), T. camphoratus (1.07 (Mg.C/ha), 18.3\%), and Vachellia etbaica (Schweinf.) (0.34 (Mg.C/ha), 5.8\%), contributed about $53 \%$ carbon stock of the total biomass (Table 1).

\subsection{Above-Ground and Below-Ground Biomass Carbon} Stocks. The mean above-ground biomass carbon (AGBC) for both uninvaded and invaded vegetation conditions was estimated to be $17.62 \mathrm{Mg} \cdot \mathrm{C} / \mathrm{ha}$ and $4.73 \mathrm{Mg} \cdot \mathrm{C} / \mathrm{ha}$, respectively (Table 1). The difference in mean aboveground carbon was found to be significant between the invaded and uninvaded vegetation conditions $(P<0.001)$. The uninvaded vegetation condition was higher than the invaded vegetation condition by about 58\% (Table 1). Similarly, the belowground carbon stock was significantly higher in the uninvaded vegetation condition compared to the invaded vegetation condition $(P<0.001)$. The below-ground carbon stock of the uninvaded vegetation condition was also higher than that of the invaded vegetation condition by about $58 \%$ (Table 1).

3.4. Soil Organic Carbon (SOC). The results in the estimation of SOC indicated that it has been reduced down across the vertical distribution of the two depths, that is, $0-15 \mathrm{~cm}$ and $15-30 \mathrm{~cm}$, for both the uninvaded and invaded vegetation conditions. The mean SOC stocks for $0-15$ to $15-30 \mathrm{~cm}$ soil 
TABLE 1: Carbon stock's potential of the top three dominant plant species in both invaded and uninvaded vegetation conditions.

\begin{tabular}{|c|c|c|c|c|c|c|}
\hline \multirow{2}{*}{ Vegetation conditions } & \multicolumn{2}{|c|}{ Dominant plant species } & \multirow{2}{*}{ AGB/ha } & \multirow{2}{*}{ AGBC } & \multirow{2}{*}{ BGBC } & \multirow{2}{*}{ TBCS } \\
\hline & Scientific name & Family & & & & \\
\hline \multirow{3}{*}{ Invaded } & Cadia purpurea Ait. & Fabaceae & 2.71 & 1.36 & 0.35 & 1.71 \\
\hline & Tarchonanthus camphorantus & Asteraceae & 1.70 & 0.85 & 0.22 & 1.07 \\
\hline & Vachellia etbaica (Schweinf.) & Fabaceae & 0.55 & 0.27 & 0.07 & 0.34 \\
\hline \multirow{3}{*}{ Uninvaded } & Olea europaea L. subsp. Cuspidata & Oleaceae & 14.64 & 7.32 & 1.9 & 9.22 \\
\hline & Juniperus procera Hochst. ex Endl. & Cupressaceae & 12.27 & 6.13 & 1.59 & 7.72 \\
\hline & Dodonaea angustifolia & Sapindaceae & 0.76 & 0.38 & 0.10 & 0.48 \\
\hline
\end{tabular}

$\mathrm{AGB}=$ above-ground biomass; $\mathrm{AGBC}=$ above-ground biomass carbon stock; $\mathrm{BGBC}=$ below-ground biomass carbon stock; $\mathrm{TBCS}=$ total biomass carbon stock.

TABLE 2: Mean $( \pm \mathrm{SD} ; N=75)$ biomass carbon stock, SOC, total carbon stock ( $\mathrm{Mg} \mathrm{C} / \mathrm{ha}), \mathrm{CO}_{2}$ sequestration $\left(\mathrm{Mg} \mathrm{C} / \mathrm{ha}\right.$ of $\mathrm{CO}_{2}$ seq.), and results of independent $t$-test (at $\alpha=0.05$ ).

\begin{tabular}{lccc}
\hline \multirow{2}{*}{ Carbon pool } & \multicolumn{2}{c}{ Vegetation conditions } & \\
& Invaded & Uninvaded & $P$ value \\
\hline AGBC & $4.73 \pm 2.68$ & $17.62 \pm 5.98$ & $P \leq 0.001$ \\
BGBC & $1.11 \pm 0.26$ & $4.14 \pm 3.23$ & $P \leq 0.001$ \\
TBC & $5.84 \pm 3.36$ & $21.76 \pm 7.13$ & $P \leq 0.001$ \\
SOC $0-15 \mathrm{~cm}$ & $47.75 \pm 11.32^{\mathrm{a}}$ & $68.02 \pm 12.42^{\mathrm{a}}$ & $P \leq 0.001$ \\
SOC $15-30 \mathrm{~cm}$ & $42.38 \pm 11.21^{\mathrm{a}}$ & $54.81 \pm 11.78^{\mathrm{b}}$ & $P \leq 0.001$ \\
SOC $0-30 \mathrm{~cm}$ & $90.13 \pm 18.67$ & $122.83 \pm 19.13$ & $P \leq 0.001$ \\
TCS & $95.97 \pm 19.71$ & $144.59 \pm 20.36$ & $P \leq 0.001$ \\
CO $_{2}$ seq. & $352.21 \pm 72.34$ & $530.65 \pm 74.72$ & $P \leq 0.001$ \\
\hline
\end{tabular}

$\mathrm{AGBC}=$ above-ground biomass carbon stock; $\mathrm{BGBC}=$ below-ground biomass carbon stock; $\mathrm{TBCS}=$ total biomass carbon stock; TCS $=$ total carbon stock; seq. = sequestration; $\mathrm{SD}=$ standard deviation. Different letters in the same column indicate significant difference $(P<0.05)$.

depths were found to be 68.02 to $54.81 \mathrm{Mg} \cdot \mathrm{C} / \mathrm{ha}$ and 47.75 to $42.38 \mathrm{Mg} / \mathrm{ha}$ in the uninvaded and invaded vegetation conditions, respectively. The difference has been found to be statistically significant at both depths in the uninvaded vegetation condition $(P<0.001$, Table 2$)$. However, the mean SOC has not shown a statistically significant difference at both depths in the invaded vegetation condition $(P=0.07$, Table 2). Moreover, the uninvaded vegetation condition displayed significantly $(p<0.01)$ higher SOC compared to the adjacent invaded vegetation condition at both depths (Table 2). The mean values of SOC stocks $(0-30 \mathrm{~cm})$ were found to be $122.83 \pm 19.13$ and $90.13 \pm 18.67 \mathrm{Mg} / \mathrm{ha}$ for both uninvaded and invaded vegetation conditions, respectively. The result showed that the mean SOC stocks were found to be significantly higher at the uninvaded vegetation condition compared with the invaded vegetation condition $(P<0.001$, Table 2).

3.5. Total Carbon Stocks and Carbon Dioxide Sequestration. The mean $( \pm S D)$ total carbon stocks were found to be $144.59 \pm 20.36$ and $95.97 \pm 19.71 \mathrm{Mg} . \mathrm{C} /$ ha for uninvaded and invaded vegetation conditions, respectively (Table 2). In all carbon pools, significantly higher carbon stocks were found in the uninvaded vegetation condition compared to the invaded vegetation condition $(P<0.001$, Table 2$)$. The $\mathrm{CO}_{2}$ sequestrations were found to be 530.65 and $352.21 \mathrm{Mg} \mathrm{Ceq/}$ ha at both uninvaded and invaded vegetation conditions,
TABle 3: Mean $( \pm S D)$ physicochemical characteristics of soils under both invaded and uninvaded vegetation conditions and results of independent $t$-test (at $\alpha=0.05$ ).

\begin{tabular}{|c|c|c|c|}
\hline \multirow{2}{*}{ Soil variable } & \multicolumn{2}{|c|}{ Vegetation conditions } & \multirow{2}{*}{$P$ value } \\
\hline & Invaded & Uninvaded & \\
\hline Sand (\%) & $30.15 \pm 11.50$ & $18.80 \pm 7.07$ & $\leq 0.001$ \\
\hline Silt (\%) & $40.20 \pm 7.82$ & $42.05 \pm 8.29$ & 0.472 \\
\hline Clay (\%) & $29.65 \pm 12.61$ & $39.15 \pm 9.53$ & 0.011 \\
\hline $\mathrm{pH}$ & $7.85 \pm 0.48$ & $8.14 \pm 0.38$ & 0.044 \\
\hline Carbon (\%) & $3.16 \pm$ & $4.82 \pm 0.75$ & $\leq 0.001$ \\
\hline Total nitro & $0.11 \pm 0.02$ & $0.096 \pm 0.02$ & 0.160 \\
\hline Availa & 0.022 & 0.029 & 0.106 \\
\hline Potassium (mg/g) & $0.16 \pm 0$ & $0.21 \pm$ & 0.048 \\
\hline $\mathrm{n}(\mathrm{mg} / \mathrm{g})$ & $8.50 \pm 3.90$ & $7.20 \pm 3.7$ & 0.295 \\
\hline$(\mathrm{mg} / \mathrm{g})$ & $0.19 \pm 0.04$ & $0.23 \pm 0.05$ & 0.016 \\
\hline Magnesium (mg/g) & $0.32 \pm 0.10$ & $0.43 \pm 0.10$ & $<0.001$ \\
\hline Manganese (mg/g) & $0.11 \pm 0.03$ & $0.13 \pm 0.04$ & 0.014 \\
\hline Iron $(\mathrm{mg} / \mathrm{g})$ & $3.1 \pm 1.10$ & $3.8 \pm 0.47$ & $\leq 0.001$ \\
\hline Copper (mg/g) & $0.020 \pm 0.01$ & $0.024 \pm 0.01$ & 0.140 \\
\hline Zinc $(\mathrm{mg} / \mathrm{g})$ & $0.020 \pm 0.01$ & $0.022 \pm 0.01$ & 0.335 \\
\hline
\end{tabular}

respectively. The $\mathrm{CO}_{2}$ sequestration in the uninvaded vegetation condition was significantly higher than that in the invaded vegetation condition $(P<0.001$, Table 2$)$.

3.6. Soil Physicochemical Characteristics. The result revealed that a higher abundance of the expansive shrubs in the invaded vegetation condition did not significantly change some of the soil characteristics, including the soil silt, nitrogen, phosphorus, calcium, copper, and zinc compared to the uninvaded vegetation condition $(P>0.05$, Table 3$)$. However, nitrogen and calcium concentrations were found to be marginally higher in the invaded vegetation condition than in the uninvaded vegetation condition. Carbon, potassium, sodium, magnesium, manganese and iron concentrations, and soil $\mathrm{pH}$ decreased significantly under expansive shrubs $(P>0.05$, Table 3$)$. In contrast, sand content was significantly higher in the invaded vegetation condition than in the uninvaded vegetation condition $(P>0.05$, Table 3$)$.

\section{Discussion}

4.1. Biomass Carbon Stocks. The biomass and biomass carbon stocks were found to be lower in the expansive shrubs in 
the invaded vegetation condition compared to the uninvaded vegetation condition of Desa'a forest. The considerable difference in total biomass carbon between the uninvaded and adjacent invaded vegetation conditions could be explained in two ways. First, an increase in abundance and expansion of the expansive species to new areas in Desa'a forest was facilitated by anthropogenic disturbances like burning, overgrazing, and overharvesting of the PNV for fuelwood, fencing, construction materials, agricultural equipment, and charcoal making $[23,30]$. Expansion of the expansive species in the area could have resulted in lower carbon stocks due to their lower $\mathrm{DBH}$. Second, the anthropogenic disturbances in the forest aggravated the PNV degradation [23] and as a result affected vegetation restoration and accumulation of aboveground biomass, where the carbon stock is determined [41]. Besides, a higher abundance of the expansive species has an impact on the number of individuals per ha and the basal area which may be the cause for the differences in the biomass carbon stock between the uninvaded and invaded vegetation conditions. For instance, Balderas and Arturo [42] stated that the basal area is a vital parameter that governs the carbon content by the species. As stated in the work of Solomon et al. [43], sites with more basal area and diameter resulted in higher carbon storage. The overall highest contribution of total biomass carbon stock by $O$. europaea and J. procera in the uninvaded vegetation condition and C. purpurea and T. camphoratus in the invaded vegetation condition could be due to the higher abundance of the plant species.

4.2. Soil Organic Carbon Stock. Soil is a vital carbon sink, holding more carbon than the total carbon in biomass and the atmosphere [44]. Our study found that SOC was higher in the surface layer $(0-15 \mathrm{~cm})$ compared to the subsurface layer $(15-30 \mathrm{~cm})$ at both the uninvaded and invaded vegetation conditions. This is in agreement with other results reporting that SOC decreases with increasing soil depths [45-49]. Various studies [50-52] have also reported a higher concentration of SOC in the top layer of soils. The higher SOC content in the surface layer of soils could be due to higher input and rapid decomposition of litter in a suitable condition. However, the decrement in SOC between the two depths $(0-15$ to $15-30 \mathrm{~cm})$ was found to be higher in the uninvaded vegetation condition than in the invaded vegetation condition. This could be attributed to the nature of the species, level of disturbance, species structure, and composition [53].

The SOC content could increase, decrease, or not change significantly in response to the expansion of expansive shrubs $[13,15,19]$. Our study found that the higher cover of the expansive shrubs caused a significant decrease in the mean SOC relative to the PNV in the uninvaded vegetation condition (Table 2). The variability may occur due to the nature of the species, growth conditions, species structure and composition, and other disturbance factors [53]. On the other hand, anthropogenic disturbances on the PNV could have two causes, (i) attribute to decrease the biomass of PNV and the subsequent production of litterfall and (ii) facilitating the expansion of the expansive shrubs which have less above-ground biomass vegetation resulting in low SOC. Accordingly, uninvaded vegetation condition with high above-ground biomass may have a higher contribution to SOC of the soil as compared to invaded vegetation condition with low above-ground biomass. The difference in SOC could also be due to shifting the PNV to expansive species in the forest, which alters the primary production, soil faunal communities, and rooting depth, which could also affect the SOC [54-56]. A previous study by Wardle [57] demonstrated that different plant species have different impacts on the activity of root biomass and soil microorganisms, which can affect SOC accumulation. Therefore, the highest SOC content in the uninvaded vegetation condition could also be due to the presence of PNV that contributed to continued production and decomposition of litter biomass. Fast nutrient decomposition rates related to high microbial activities have been reported by Yelenik et al. [25] and Valéry et al. [5] following the expansion of Vachellia saligna and Elymus athericus, respectively. On the contrary, slow microbial nutrient decomposition has been reported in the area invaded by Eucalyptus camaldulensis [17].

4.3. Soil Physicochemical Properties. We argued that the differences in soil properties between the invaded and uninvaded vegetation conditions were caused by the direct and indirect effects of the trees and shrubs found in each vegetation condition. Furthermore, the relatively higher concentration of nitrogen in the invaded vegetation condition could be due to the nitrogen-fixing ability of the expansive species, namely, T. camphoratus [58]. The relatively higher concentration of calcium in our result was in agreement with the study by Sholto-Douglas et al. [3], which reported high calcium under the expansive species of Dicerothamnus rhinocerotis and Pteronia incana invaded sites. The significant difference in soil $\mathrm{pH}$ between the invaded and uninvaded vegetation conditions was consistent with previous studies $[3,6,59-61]$ which reported that plant invasion and expansion significantly elevate soil $\mathrm{pH}$ values. The $\mathrm{pH}$ value of this study was found to be low compared to that in the study by Ward et al. [6] under the soil of T. camphoratus.

High variability in soil physicochemical characteristics in response to the expansion of plant species has been reported in other studies. Previous studies have reported both increased $[1,3,25,62]$ and decreased $[3,63]$ values of soil properties under invasive and expansive plant species invaded sites compared to uninvaded sites. The variations may be caused by several reasons, among which the most important are functional traits of the expansive species and $\mathrm{PNV}$, differences in plant phenology and morphology that initiated different effects on sites, environmental factors, and the soil microbial community $[64,65]$. Besides, herbaceous cover is suppressed with increase in the cover of the expansive shrubs, which increases soil erosion that could cause nutrient loss to be the reason for the variation $[23,66]$. Litter decomposition rate variation has also been considered to explain changes in soil nutrients due to the expansion of 
expansive species. Some invasive or expansive species can increase the microbial activities resulting in a fast nutrient decomposition rate as they have been reported by Yelenik et al. [25] and Valéry et al. [5] following the invasion of Vachellia and the expansion of Elymus athericus, respectively, and slow nutrient decomposition as reported by Tererai et al. [17] following the invasion of Eucalyptus camaldulensis.

\section{Conclusion}

This study revealed that all measured carbon stocks were found to be lower under the expansive shrubs in the forest. The total mean carbon biomass and soil organic carbon stock of the uninvaded vegetation condition were higher than those of the invaded vegetation condition. The carbon dioxide sequestration potential of the forest has been found to be lower under the expansive shrubs. Different soil characteristics have been observed under the canopies of PNV in the uninvaded vegetation condition in comparison to the soil from the canopies of the expansive shrubs from the invaded vegetation condition. Most of the soil physicochemical properties were significantly lower in the expansive shrubs of invaded vegetation condition except for significantly higher sand content. Some of the soil properties such as silt, nitrogen, calcium, copper, and zinc did not significantly change with the cover of the expansive species compared to PNV. Hence, to enhance the carbon storage potential and to maintain the soil nutrient status of the forest, proper conservation, monitoring, and management of the existing PNV and controlling a further expansion of the expansive shrubs are required.

\section{Data Availability}

The data used to support the findings of this study are available from the corresponding author upon request.

\section{Conflicts of Interest}

The authors declare that they have no conflicts of interest.

\section{Acknowledgments}

This work was supported by Mekelle University and the MUHU-NMBU institutional collaboration project.

\section{References}

[1] C. Liao, R. Peng, Y. Luo et al., "Altered ecosystem carbon and nitrogen cycles by plant invasion: a meta-analysis," New Phytologist, vol. 177, no. 3, pp. 706-714, 2008.

[2] D. A. Peltzer, R. B. Allen, G. M. Lovett, D. Whitehead, and D. A. Wardle, "Effects of biological invasions on forest carbon sequestration," Global Change Biology, vol. 16, no. 2, pp. 732-746, 2010.

[3] C. Sholto-Douglas, C. M. Shackleton, S. Ruwanza, and T. Dold, "The effects of expansive shrubs on plant species richness and soils in semi-arid communal lands, South Africa," Land Degradation \& Development, vol. 28, no. 7, pp. 2191-2206, 2017.
[4] D. Simberloff, J.-L. Martin, P. Genovesi et al., "Impacts of biological invasions: what's what and the way forward," Trends in Ecology \& Evolution, vol. 28, no. 1, pp. 58-66, 2013.

[5] L. Valéry, V. Bouchard, and J.-C. Lefeuvre, "Impact of the invasive native species Elymus athericus on carbon pools in a salt marsh," Wetlands, vol. 24, no. 2, pp. 268-276, 2004.

[6] D. Ward, J. Trinogga, K. Wiegand et al., "Large shrubs increase soil nutrients in a semi-arid savanna," Geoderma, vol. 310, pp. 153-162, 2018.

[7] D. J. Eldridge, M. A. Bowker, F. T. Maestre, E. Roger, J. F. Reynolds, and W. G. Whitford, "Impacts of shrub encroachment on ecosystem structure and functioning: towards a global synthesis," Ecology Letters, vol. 14, no. 7, pp. 709-722, 2011.

[8] P. Pyšek, D. M. Richardson, M. Rejmánek, G. L. Webster, M. Williamson, and J. Kirschner, "Alien plants in checklists and floras: towards better communication between taxonomists and ecologists," Taxon, vol. 53, no. 1, pp. 131-143, 2004.

[9] P. Kelbel and Z. Adamčíková, "Selected invasive and expansive tree species in conditions of the botanical garden of PJ Šafárik University in Košice," Thaiszia-Journal of Botany, vol. 21, pp. 141-152, 2011.

[10] J. Möllerová, "Notes on invasive and expansive trees and shrubs," Journal of Forest Science, vol. 51, pp. 19-23, 2005.

[11] G. Sharma, J. Singh, and A. Raghubanshi, "Plant invasions: Emerging trends and future implications," Current Science, vol. 88, no. 5, pp. 726-734, 2021.

[12] M. Bottollier-Curtet, A.-M. Planty-Tabacchi, and E. Tabacchi, "Competition between young exotic invasive and native dominant plant species: implications for invasions within Riparian areas," Journal of Vegetation Science, vol. 24, no. 6, pp. 1033-1042, 2013.

[13] S. T. Brantley and D. R. Young, "Shrub expansion stimulates soil C and N storage along a coastal soil chronosequence," Global Change Biology, vol. 16, no. 7, pp. 2052-2061, 2010.

[14] J. G. Ehrenfeld, "Ecosystem consequences of biological invasions," Annual Review of Ecology, Evolution, and Systematics, vol. 41, no. 1, pp. 59-80, 2010.

[15] R. B. Jackson, J. L. Banner, E. G. Jobbágy, W. T. Pockman, and D. H. Wall, "Ecosystem carbon loss with woody plant invasion of grasslands," Nature, vol. 418, no. 6898, pp. 623-626, 2002.

[16] M. Te Beest, K. J. Esler, and D. M. Richardson, "Linking functional traits to impacts of invasive plant species: a case study," Plant Ecology, vol. 216, no. 2, pp. 293-305, 2015.

[17] F. Tererai, M. Gaertner, S. M. Jacobs, and D. M. Richardson, "Eucalyptus camaldulensis invasion in riparian zones reveals few significant effects on soil physico-chemical properties," River Research and Applications, vol. 31, no. 5, pp. 590-601, 2015.

[18] D. C. McKinley and J. M. Blair, "Woody plant encroachment by juniperus virginiana in a mesic native grassland promotes rapid carbon and nitrogen accrual," Ecosystems, vol. 11, no. 3, pp. $454-468,2008$.

[19] H. L. Throop, K. Lajtha, and M. Kramer, "Density fractionation and $13 \mathrm{C}$ reveal changes in soil carbon following woody encroachment in a desert ecosystem," Biogeochemistry, vol. 112, no. 1-3, pp. 409-422, 2013.

[20] H. Li, H. Shen, L. Chen et al., "Effects of shrub encroachment on soil organic carbon in global grasslands," Scientific Reports, vol. 6, no. 1, p. 28974, 2016.

[21] C. Coetsee, E. F. Gray, J. Wakeling, B. J. Wigley, and W. J. Bond, "Low gains in ecosystem carbon with woody plant encroachment in a South African Savanna," Journal of Tropical Ecology, vol. 29, no. 1, pp. 49-60, 2013. 
[22] A. Chiarucci, M. B. Araújo, G. Decocq, C. Beierkuhnlein, and J. M. Fernández-Palacios, "The concept of potential natural vegetation: an epitaph?" Journal of Vegetation Science, vol. 21, no. 6, pp. 1172-1178, 2010.

[23] M. Haile, E. Birhane, M. M. Rannestad, and M. S. Adaramola, "Expansive shrubs: expansion factors and ecological impacts in Northern Ethiopia," Journal for Nature Conservation, vol. 61, p. 125996, 2021.

[24] S. Seitz, P. Goebes, Z. Song et al., "Tree species and functional traits but not species richness affect interrill erosion processes in young subtropical forests," Soil, vol. 2, no. 1, pp. 49-61, 2016.

[25] S. G. Yelenik, W. D. Stock, and D. M. Richardson, "Ecosystem level impacts of invasive Acacia saligna in the South African fynbos," Restoration Ecology, vol. 12, no. 1, pp. 44-51, 2004.

[26] H. Hishe, "Spatio-temporal analysis of major species dynamics in Desa'a forest using subpixel classifier and NDVI modelling, Northern Ethiopia," M.Sc thesis, Bahr Dar University, Bahir Dar, Ethiopia, 2013.

[27] H. Hishe, K. Giday, M. Neka, T. Soromessa, J. V. Orshoven, and B. Muys, "Detection of olea europaea subsp. cuspidata and Juniperus procera in the dry afromontane forest of Northern Ethiopia using subpixel analysis of landsat imagery," Journal of Applied Remote Sensing, vol. 9, no. 1, pp. 1-10, 2015.

[28] T. Berihu, G. Girmay, M. Sebhatleab, E. Berhane, A. Zenebe, and G. C. Sigua, "Soil carbon and nitrogen losses following deforestation in Ethiopia," Agronomy for Sustainable Development, vol. 37, no. 1, p. 1, 2016.

[29] E. Aynekulu Betemariam, Forest Diversity in Fragmented Landscapes of Northern Ethiopia and Implications for Conservation, ZEF, New York, NY, USA, 2011.

[30] Z. Gebreegziabher, “Dessa'a protected area: an assessment of human impact, evolutionary pattern and options for sustainable management," Mekelle, Ethiopia Personal Interview $M$, vol. 5, pp. 15-64, 1999.

[31] A. El-Keblawy and A. Al-Rawai, "Impacts of the invasive exotic Prosopis juliflora (Sw.) D.C. on the native flora and soils of the UAE," Plant Ecology, vol. 190, no. 1, pp. 23-35, 2007.

[32] D. Ellenberg and D. Mueller-Dombois, Aims and Methods of Vegetation Ecology, Wiley, New York, NY, USA, 1974.

[33] G. M. Muturi, L. Poorter, G. M. J. Mohren, and B. N. Kigomo, "Ecological impact of prosopis species invasion in Turkwel riverine forest, Kenya," Journal of Arid Environments, vol. 92, pp. 89-97, 2013.

[34] B. A. Tetemke, E. Birhane, M. M. Rannestad, and T. Eid, "Allometric models for predicting aboveground biomass of trees in the dry Afromontane forests of Northern Ethiopia," Forests, vol. 10, no. 12, p. 1114, 2019.

[35] IPCC, Good Practice Guidance for Land Use, Land-Use Change and Forestry, IPCC National Greenhouse Gas Inventories Programme-Technical Support Unit, Hayama, Japan, 2006, http://www.ipcc-nggip.iges.or.jp.

[36] S. Brown, "Measuring carbon in forests: current status and future challenges," Environmental Pollution, vol. 116, no. 3, pp. 363-372, 2002.

[37] T. Pearson, S. Brown, and R. Birdsey, Measurement Guidelines for the Sequestration of Forest Carbon, United States Department of Agriculture, Washington, DC, USA, 2007.

[38] L. Van Reeuwijk, Procedures for Soil Analysis, ISRIC, Wageningen, The Netherlands, 3rd edition, 1992.

[39] A. Walkley and I. A. Black, "An examination of the degtjareff method for determining soil organic matter, and a proposed modification of the chromic acid titration method," Soil Science, vol. 37, no. 1, pp. 29-38, 1934.

[40] R Core Team, R: A Language and Environment for Statistical Computing, R Foundation for Statistical Computing, Vienna, Austria, 2019.

[41] W. Mekuria, M. Wondie, T. Amare, A. Wubet, T. Feyisa, and B. Yitaferu, "Restoration of degraded landscapes for ecosystem services in North-Western Ethiopia," Heliyon, vol. 4, no. 8, Article ID e00764, 2018.

[42] T. Balderas, L. Arturo, and C. Jon, "Using basal area to estimate aboveground carbon stocks in forests: la primavera biosphere's reserve, Mexico," Forestry: an International Journal of Forest Research, vol. 86, no. 2, pp. 267-281, 2012.

[43] N. Solomon, E. Birhane, T. Tadesse, A. C. Treydte, and K. Meles, "Carbon stocks and sequestration potential of dry forests under community management in Tigray, Ethiopia," Ecological Processes, vol. 6, no. 1, p. 20, 2017.

[44] R. S. Swift, "Sequestration of carbon by soil," Soil Science, vol. 166, no. 11, pp. 858-871, 2001.

[45] N. G. Bikila, Z. K. Tessema, and E. G. Abule, "Carbon sequestration potentials of semi-arid rangelands under traditional management practices in Borana, Southern Ethiopia," Agriculture, Ecosystems \& Environment, vol. 223, pp. 108-114, 2016.

[46] A. J. Fynn, P. Alvarez, J. R. Brown et al., Soil Carbon Sequestration in US Rangelands, FAO, Rome, Italy, 2009.

[47] M. A. Sheikh, M. Kumar, and R. W. Bussmann, "Altitudinal variation in soil organic carbon stock in coniferous subtropical and broadleaf temperate forests in Garhwal Himalaya," Carbon Balance and Management, vol. 4, no. 1, p. 6, 2009.

[48] G. Swai, H. J. Ndangalasi, P. K. T. Munishi, and D. D. Shirima, "Carbon stocks of Hanang forest, Tanzania: an implication for climate mitigation," Journal of Ecology and the Natural Environment, vol. 6, no. 3, pp. 90-98, 2014.

[49] F. Yimer, S. Ledin, and A. Abdelkadir, "Soil organic carbon and total nitrogen stocks as affected by topographic aspect and vegetation in the Bale Mountains, Ethiopia," Geoderma, vol. 135, pp. 335-344, 2006.

[50] M. S. Hossain Chowdhury, S. Biswas, M. A. Halim, S. M. Sirajul Haque, N. Muhammed, and M. Koike, "Comparative analysis of some selected macronutrients of soil in orange orchard and degraded forests in Chittagong Hill Tracts, Bangladesh," Journal of Forestry Research, vol. 18, no. 1, pp. 27-30, 2007.

[51] J. Mendoza-Vega, E. Karltun, and M. Olsson, "Estimations of amounts of soil organic carbon and fine root carbon in land use and land cover classes, and soil types of Chiapas highlands, Mexico," Forest Ecology and Management, vol. 177, no. 1-3, pp. 191-206, 2003.

[52] M. R. Ullah and M. Al-Amin, "Above-and below-ground carbon stock estimation in a natural forest of Bangladesh," Journal of Forest Science, vol. 58, no. 8, pp. 372-379, 2012.

[53] S. S. Khadanga and S. Jayakumar, "Tree biomass and carbon stock: understanding the role of species richness, elevation, and disturbance," Tropical Ecology, vol. 61, no. 1, pp. 128-141, 2020.

[54] R. B. Jackson, H. J. Schenk, E. G. Jobbágy et al., "Belowground consequences of vegetation change and their treatment in models," Ecological Applications, vol. 10, no. 2, pp. 470-483, 2000.

[55] E. G. Jobbágy and R. B. Jackson, "The vertical distribution of soil organic carbon and its relation to climate and 
vegetation," Ecological Applications, vol. 10, no. 2, pp. 423-436, 2000.

[56] S. E. Trumbore, "Potential responses of soil organic carbon to global environmental change," Proceedings of the National Academy of Sciences, vol. 94, no. 16, pp. 8284-8291, 1997.

[57] D. A. Wardle, Communities and Ecosystems: Linking the Aboveground and Belowground Components (MPB-34), Vol. 34, Princeton University Press, Princeton, NJ, USA, 2013.

[58] N. Oduor, Sustainable Feedstock Management for Charcoal Production in Kenya: Resources, Initiatives and Options, Practical Action Consulting, Rugby, UK, 2012.

[59] J. G. Ehrenfeld, P. Kourtev, and W. Huang, "Changes in soil functions following invasions of exotic understory plants in deciduous forests," Ecological Applications, vol. 11, no. 5, pp. 1287-1300, 2001.

[60] L. Fan, Y. Chen, J.-G. Yuan, and Z.-Y. Yang, "The effect of lantana camara linn. invasion on soil chemical and microbiological properties and plant biomass accumulation in Southern China," Geoderma, vol. 154, no. 3-4, pp. 370-378, 2010.

[61] S. E. Kuebbing, A. T. Classen, and D. Simberloff, "Two cooccurring invasive woody shrubs alter soil properties and promote subdominant invasive species," Journal of Applied Ecology, vol. 51, no. 1, pp. 124-133, 2014.

[62] S. Vanderhoeven, N. Dassonville, and P. Meerts, "Increased topsoil mineral nutrient concentrations under exotic invasive plants in Belgium," Plant and Soil, vol. 275, no. 1-2, pp. 169-179, 2005.

[63] J. K. Leary, N. V. Hue, P. W. Singleton, and D. Borthakur, "The major features of an infestation by the invasive weed legume gorse (Ulex europaeus) on volcanic soils in Hawaii," Biology and Fertility of Soils, vol. 42, no. 3, pp. 215-223, 2006.

[64] N. Dassonville, S. Vanderhoeven, V. Vanparys, M. Hayez, W. Gruber, and P. Meerts, "Impacts of alien invasive plants on soil nutrients are correlated with initial site conditions in NW Europe," Oecologia, vol. 157, no. 1, pp. 131-140, 2008.

[65] H.-B. Shao, L.-Y. Chu, C. A. Jaleel, and C.-X. Zhao, "Waterdeficit stress-induced anatomical changes in higher plants," Comptes Rendus Biologies, vol. 331, no. 3, pp. 215-225, 2008.

[66] V. Kakembo and K. M. Rowntree, "The relationship between land use and soil erosion in the communal lands near Peddie town, Eastern Cape, South Africa," Land Degradation \& Development, vol. 14, no. 1, pp. 39-49, 2003. 